(C) [2007] IEEE. Reprinted, with permission, from David G. Dorrell, Design Requirements for Brushless Permanent Magnet Generators for Use in Small Renewable Energy Systems, Industrial Electronics Society, 2007. IECON 2007. 33rd Annual Conference of the IEEE 5-8 Nov. 2007]. This material is posted here with permission of the IEEE. Such ermission of the IEEE does not in any way imply IEEE endorsement of any of the University of Technology, Sydney's products or services. Internal or personal use of this material is permitted. However, permission to reprint/republish this material for advertising or promotional purposes or for creating new collective works for resale or redistribution must be obtained from the IEEE by writing to pubs-permissions@ieee.org. By choosing to view this document, you agree to all provisions of the copyright laws protecting it 


\title{
Design Requirements for Brushless Permanent Magnet Generators for Use in Small Renewable Energy Systems
}

\author{
David G. Dorrell, Member IEEE \\ University of Glasgow, Glasgow, G12 8LT, UK \\ D.Dorrell@elec.gla.ac.uk
}

\begin{abstract}
This paper reviews some of the arrangements and connection requirements for a permanent-magnet generator. It illustrates the importance of winding reactance minimization when using a diode bridge rectifier. It uses modern CAD methods to design a small PM generator and verifies the performance using simulation software. The design is modified to improve the generator size. This highlights that increasing the electrical loading in an attempt to reduce the generator size can lead to a large reduction in power factor, where a controlled rectifier would have to be used instead of a diode bridge rectifier.
\end{abstract}

Index terms- permanent magnet generator, diode bridge

\section{INTRODUCTION}

There is much literature that details the design of small 3phase brushless permanent-magnet motors. These utilize a shaft encoder or Hall probes depending on whether it is a.c. or d.c. control. This will ensure that the current is maintained on the $\mathrm{q}$ axis or an appropriate advance (for field weakening). It is possible to control the machine in a similar fashion when generating. In this situation power flows out of the machine terminals whereas reactive power flows into the machine to supply the VAr requirement of the synchronous (or phase) reactance [1][2].

However, this is often too complicated for many small generator applications (such as small wind turbines) and the use of a diode bridge is preferable, often with some capacitor compensation across the generator terminals [3][4][5]. A d.c. to d.c. chopper, battery and inverter can then be used to condition the power and provide a stable output. This requires good output regulation from the machine, i.e., minimization of the synchronous reactance. It is not a simple matter of utilizing a standard brushless permanent magnet motor. Many designs use coreless designs to reduce the synchronous reactance. In addition axial flux machines are utilized in these applications [6] and also torus machines [7]. In stand-alone diesel generators, the speed is fixed and the machine can be connected directly to the load with a VAr compensator connected in parallel with the load to regulate the voltage [8]. More standard radial-flux machines can be used in permanentmagnet generators and several designs have been reported [9][10]. They are often required to be low speed in nature [11] and be modular [12].

One of the main applications for the permanent magnet generator is the wind turbine. Many smaller systems are direct drive since they operate at higher turbine speeds while large turbines operate at much lower speeds via a gearbox. It is possible to use direct drive in large turbines and the different systems were reviewed in [13].

The paper will review the systems that are utilized in small systems then set out the design of a radial-flux brushless permanent-magnet generator and simulate the machine in conjunction with a 3-phase bridge rectifier. This process will utilize SPEED motor design software and also Portunus system simulation.

\section{LOAD REQUIREMENTS}

It is first worth reviewing the load requirements for a generator in order to assess the performance.

\section{A. Single-Phase Small Fixed Load and Variable Speed}

This is a very established and very basic form of singlephase permanent magnet generator and the type found in bicycle dynamo systems. It relies on having a matched load (of, say, two $5 \mathrm{~W} 12 \mathrm{~V}$ lamps) so that once a base speed is reached, the generator will deliver constant power over a wide speed range. If the back-EMF induced into the 2-pole dynamo is $E_{d}$ then

$$
E_{d}=K_{E} \omega_{d}=\left(j \omega_{d} L_{d}+r_{d}+R_{\text {load }}\right) I_{d}
$$

where $K_{E}$ is the generator back-EMF constant ( $\left.\mathrm{Vs} / \mathrm{rad}\right), L_{d}$ is the dynamo inductance, $r_{d}$ is the winding resistance and $R_{\text {load }}$ is the combined lamp resistance. The current $I_{d}$ can be approximated when the winding reactance is much greater than the load resistance so that

$$
I_{d}=\left.\left|\frac{K_{E} \omega_{d}}{\left(j \omega_{d} L_{d}+r_{d}+R_{\text {load }}\right)}\right| \approx \frac{K_{E}}{L_{d}}\right|_{\omega_{d} L_{d} \gg R_{\text {load }}}
$$

and the terminal voltage is

$$
V_{d}=\left.\left|\frac{R_{\text {load }} K_{E} \omega_{d}}{\left(j \omega_{d} L_{d}+r_{d}+R_{\text {load }}\right)}\right| \approx \frac{R_{\text {load }} K_{E}}{L_{d}}\right|_{\omega_{d} L_{d} \gg R_{\text {load }}}
$$

This illustrates that if the load is matched to the dynamo, a constant voltage and current are obtained above the base speed. A change in load will result in a change in power delivered to the load.

\section{B. 3-Phase Brushless Permanent Magnet Motor Example}

To carry out an investigation into the operation of a brushless permanent magnet motor when used as a generator it was decided to use a 8 pole rare-earth example manufactured for utilization in a pump (an SQFlex water pump motor from 
Grundfos, Denmark). The machine was rated at $2.5 \mathrm{Nm}$ at $3000 \mathrm{rpm}$. The motor parameters are given in Table I.

TABLE I

8-POLE 3-PHASE SQ FleX MOtor PARAMETERS (MOTORING)

\begin{tabular}{|c|c|c|c|}
\hline Parameter & Value & Parameter & Value \\
\hline DC Rail Voltage (Line) & $300 \mathrm{~V}$ & Phase Resistance & $1 \mathrm{ohm}$ \\
\hline Torque & $2.5 \mathrm{Nm}$ & Rated Current & $4.3 \mathrm{~A}$ \\
\hline Maximum Speed & $3000 \mathrm{rpm}$ & Rated Power & $785 \mathrm{~W}$ \\
\hline Measured Voltage & 33.6 & Measured Phase & 5.25 \\
Constant (Line voltage) & $\mathrm{mV} / \mathrm{rpm}$ & Inductance & $\mathrm{mH}$ \\
\hline Pole number & 8 & Connection & Star \\
\hline
\end{tabular}

At rated speed the frequency is $200 \mathrm{~Hz}$; therefore to connect it directly to a $50 \mathrm{~Hz}$ supply the speed is de-rated to $750 \mathrm{rpm}$ and the power to $187.5 \mathrm{~W}$. At $3000 \mathrm{rpm}$ the torque is rated at 2.5 $\mathrm{Nm}$ with a phase back-EMF of $60 \mathrm{~V}$. Assuming the current is on the $\mathrm{q}$ axis then this represents a current of $4.3 \mathrm{~A}$. The wire has a diameter of $0.56 \mathrm{~mm}$ meaning the current density is about $17 \mathrm{~A} / \mathrm{mm}^{2}$. This seems high for a naturally ventilated machine, however, this machine is water cooled using the pumped fluid. In motoring mode the phasor diagram is as shown in Fig. 1 (taken from a SPEED PC-BDC model of the machine - which is an industry-standard brushless permanent-magnet motor CAD software package), which shows that the voltage drop across the phase reactance $X_{s}$ is low. This is a good characteristic in a machine for use as a generator. Many permanent magnet machines will have a voltage drop in the region of 1 p.u. whereas this is in the region of 0.37 (with reference to the terminal voltage). This machine has a novel form of manufacture and has coils that are concentrated around one tooth. The cross section and winding are shown in Fig. 2. We will use this to examine the behavior of the machine when utilized as a generator in different situations. The open-circuit back-EMF is shown in Fig. 3. This was obtained from the PC$\mathrm{BDC}$ simulation. The harmonic content of the phase voltage waveform gives a fundamental with a peak of $89.2 \mathrm{~V}$ and a $5^{\text {th }}$ harmonic of $18.7 \%$.

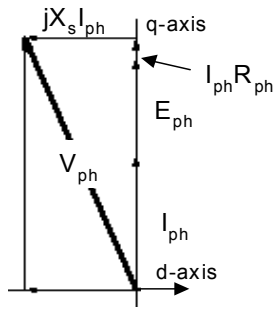

Fig. 1. Motoring phasor diagram at full load and maximum speed.
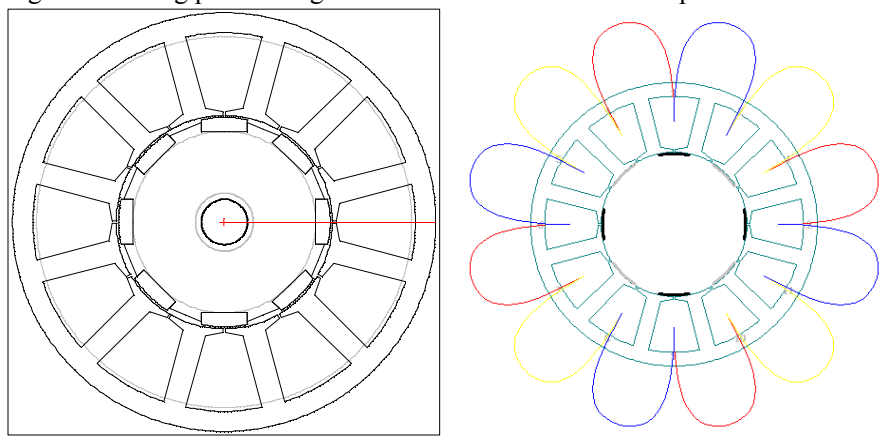

Fig. 2. Motor cross-section and winding layout.

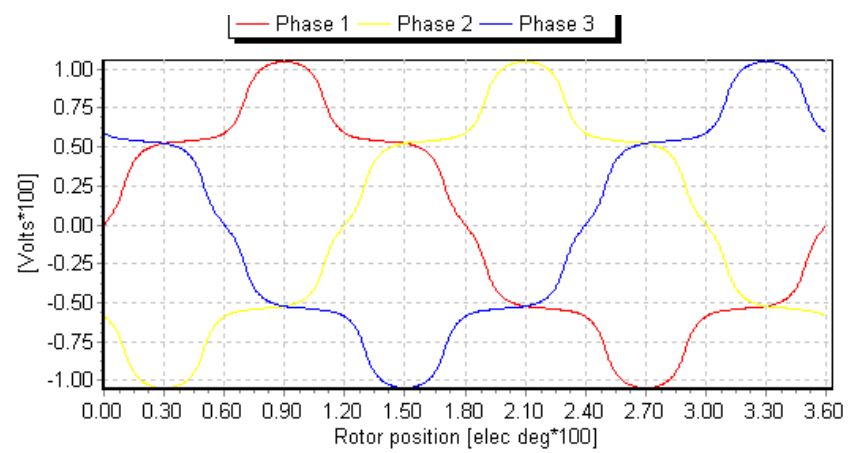

Fig. 3. Open-circuit back-EMF from SPEED PC-BDC.

\section{Fixed Speed Operation Connected to AC Supply}

If the machine is directly connected to an a.c. supply then the back-EMF at $50 \mathrm{~Hz}$ is $15 \mathrm{~V}$ giving a potential of $190 \mathrm{~W}$ of generation at a speed of $750 \mathrm{rpm}$. When the machine is operated under these conditions it will behave as an underexcited synchronous machine. The terminal voltage should be tied down to $15 \mathrm{~V}$ (the back-EMF). Obviously if it was connected to a $400 \mathrm{~V} 50 \mathrm{~Hz}$ supply (UK system) then a step-up transformer can be used, with the regulation of the transformer allowing an increase of the machine terminal voltage.

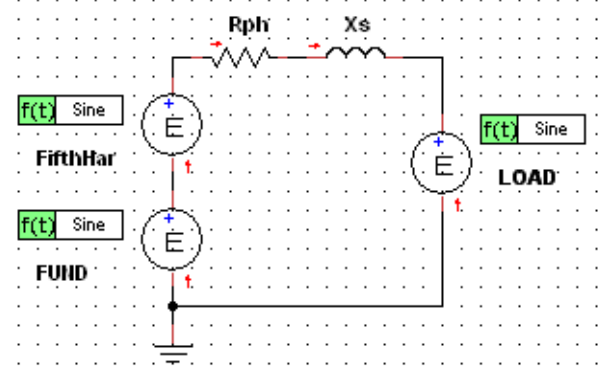

Fig. 4. Portunus per-phase model for fixed-frequency operation.

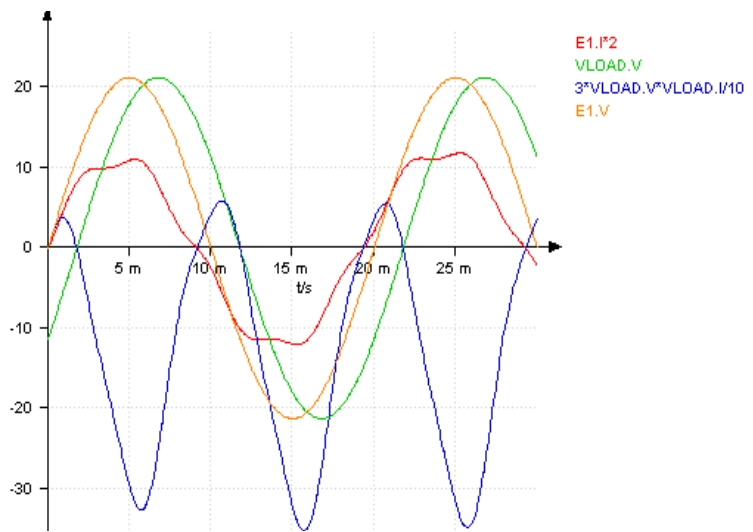

Fig. 5. Back-EMF, load voltage, load current and instantaneous power flow with load angle between back-EMF and load voltage of $32 \mathrm{deg}$ (750 rpm and controlled rectifier loading).

The machine can be modeled in a simulation package to represent the system. This is shown in Fig. 4 where Portunus from Adapted Solutions was used to simulate a per-phase machine equivalent circuit. The model consisted of the fundamental and $5^{\text {th }}$ harmonic voltage sources together with a 1 ohm winding resistance and $5.25 \mathrm{mH}$ inductance. The load is a $15 \mathrm{~V}$ (rms) voltage source. At $50 \mathrm{~Hz}$ the impedance of the 
winding is $|1+\mathrm{j} 1.64|=1.92 \mathrm{ohm}$. Therefore voltage drop at $4.3 \mathrm{~A}$ is $8.3 \mathrm{~V}$. Considering the $15 \mathrm{~V}$ fundamental back-EMF of the machine means that the load angle $\delta$ between the load and fundamental can be set to $\sin (2 \delta)=8.3 / 2 \times 15$, so that $\delta=$ $32^{\circ}$ (where the load voltage lags the back-EMF). The waveforms for the back-EMF (E1), load voltage, current and instantaneous power are shown in Fig. 5 (current and power scaled). The peak current is $5.55 \mathrm{~A}$ and contains $5^{\text {th }}$ harmonic (compared to 6.08 A calculated with no harmonic). The delivered mean power is $135 \mathrm{~W}$ with $55.5 \mathrm{~W}$ of copper loss. This illustrates the issue with low voltage generators - they can be low efficiency due to the high p.u. copper loss. It can also be seen that there is a phase difference between the terminal voltage and current - the current is leading because load is supplying the machine with the reactive power absorbed by the winding reactance.

\section{Variable Speed Operation with Varying Load}

To drive the machine over a range of speeds then it is necessary to use a rectifier of some description. To maximize the operation then a controlled rectifier has to be utilized. If the generator is used with a wind turbine system then the wind power is a cube function of the wind speed. However, turbine systems tend to be designed so that the electrical power delivered is proportional to the turbine speed up to a base speed then runs at constant power up to the maximum speed. This matches well the operation of a brushless machine. The same circuit in Fig. 4 can be used to test the system when the load voltage and frequency are varied. If the system begins generating at $50 \mathrm{~Hz}$ and moves up to $200 \mathrm{~Hz}$ the results for the low speed operation are given in the previous section while the high speed operation at $200 \mathrm{~Hz}$ is shown in Table II (controlled rectifier results). The waveforms are shown in Fig. 6.

TABLE II

8-Pole 3-Phase SQ Flex Motor Acting as Generator With CONTROLLED RECTIFIER AND RESISTIVE LOAD AT 750 RPM AND 3000 RPM

\begin{tabular}{|l|l|l|l|l|}
\hline & \multicolumn{2}{|c|}{$\begin{array}{c}\text { Controlled } \\
\text { Rectifier }\end{array}$} & \multicolumn{2}{c|}{$\begin{array}{c}\text { Resistive Load } \\
\text { (Diode Bridge) }\end{array}$} \\
\hline Parameter & $\begin{array}{l}\text { Low } \\
\text { Speed }\end{array}$ & $\begin{array}{l}\text { High } \\
\text { Speed }\end{array}$ & $\begin{array}{l}\text { Low } \\
\text { Speed }\end{array}$ & $\begin{array}{l}\text { High } \\
\text { Speed }\end{array}$ \\
\hline Speed [rpm] & 750 & 3000 & 750 & 3000 \\
\hline Back-EMF $E p h[\mathrm{~V}]$ & 15 & 60 & 15 & 60 \\
\hline Load angle $\delta[\mathrm{deg}]$ & 32 & 27.7 & 21.8 & 22.3 \\
\hline Terminal phase voltage $V p h[\mathrm{~V}]$ & 15 & 60 & 8.86 & 53 \\
\hline Iph $[\mathrm{A}]$ & 4.3 & 4.44 & 4.3 & 4.0 \\
\hline Angle between $E p h$ and $I p h[\mathrm{deg}]$ & 0 & 5 & 21.8 & 22.3 \\
\hline Pout $[\mathrm{W}]$ & 135 & 787.5 & 95 & 520 \\
\hline Qin $[\mathrm{VAr}]$ & 135 & 385 & 0 & 0 \\
\hline p.f. [p.u.] & 0.707 & 0.876 & $\approx 1$ & $\approx 1$ \\
\hline Cu Loss [W] & 55.5 & 59.2 & 55.5 & 55.5 \\
\hline
\end{tabular}

\section{E. Diode Bridge Operation}

In the previous section it was assumed that a controlled rectifier was used. This can be a complex system. The current has to be maintained on the motor q-axis. The reactance of the machine is quite low so we can now investigate the performance when a simple diode bridge is used. A diode bridge effectively acts as a load resistor so cannot supply any reactive power to the machine.
The system is shown in Fig. 7. This includes the fifth voltage harmonic in the back-EMF and also the phase resistance and inductance. The diode bridge includes diode voltage drop.

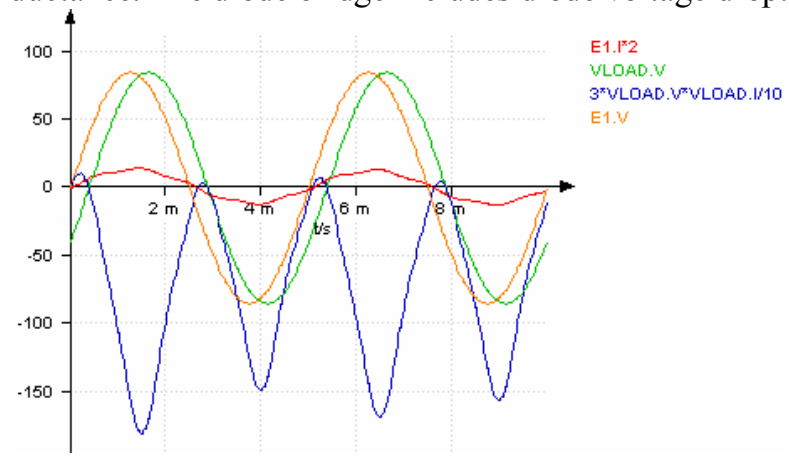

Fig. 6. Back-EMF, load voltage, load current and instantaneous power flow with load angle between back-EMF and load voltage of 27.7 deg (3000 rpm and controlled rectifier loading).

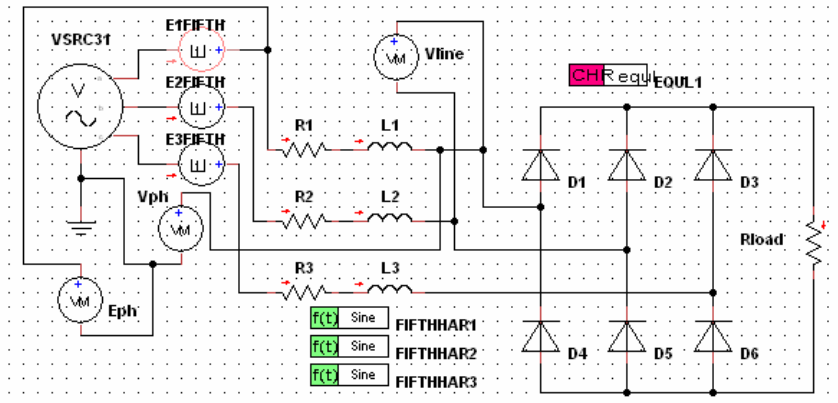

Fig. 7. Portunus machine model including fifth voltage harmonic, phase resistance and inductance, and diode bridge rectifier.

To calculate the required resistance it is necessary to refer the rectified voltage $V_{D C}$ to the rms machine terminal voltage $V_{p h}$. This can be calculated to be

$$
V_{D C}=\frac{3 \sqrt{6}}{\pi} V_{p h}
$$

Following this through then the per-phase equivalent resistance $R_{\text {per-phase }}^{\prime}$ for the bridge load resistance $R_{\text {Load }}$ is

$$
R_{\text {per-phase }}^{\prime}=\frac{\pi^{2}}{18} R_{\text {Load }}
$$

If the maximum current is known, the equivalent circuit resistance $R_{\text {per-phase }}^{\prime}$ can be calculated from

$$
\frac{E_{p h}}{I_{p h}}=\sqrt{\left(R_{p h}+R_{p e r-p h a s e}^{\prime}\right)^{2}+X_{S}^{2}}
$$

For the low speed example in the previous section $I_{p h}=4.3$ $\mathrm{A}$ and $E_{p h}=15 \quad \mathrm{~V}$. Hence $R_{\text {per-phase }}^{\prime}=2.06 \Omega$ and $R_{\text {Load }}=3.76 \Omega$. The theoretical power in the equivalent load resistances is $114 \mathrm{~W}$ where $V_{p h}=8.86 \mathrm{~V}$ and $V_{D C}=20.7 \mathrm{~V}$. The power dissipated in the bridge load resistance is then $20.7^{2} / 3.76=114 \mathrm{~W}$. However, the bridge diodes have a forward voltage drop of $0.8 \mathrm{~V}$ therefore the power delivered to the load becomes $19.1^{2} / 3.76=97 \mathrm{~W}$. The waveforms for the power, back-EMF, phase voltage and phase current are shown in Fig. 8 while the results are tabulated in Table II. The power delivered to the bridge resistance is just under $100 \mathrm{~W}$. 
Compare this with a controlled bridge rectifier where the power drawn from the generator is $135 \mathrm{~W}$. This illustrates that the output power is reduced by $30 \%$ due to the use of a resistive load rather than a controlled rectifier. The power delivery can be improved by use of an active VAr compensator across the machine terminals but this is quite complicated for a simple small generator system.

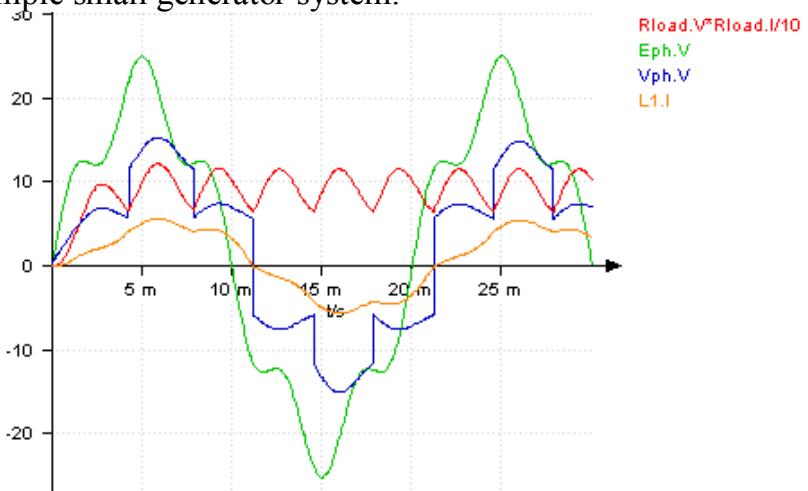

Fig. 8. Instantaneous power flow, back-EMF, load voltage and load current with diode bridge rectifier at $750 \mathrm{rpm}$.

At high speed the results are shown in Table II. The diode bridge load resistor $R_{\text {Load }}=20.6 \Omega$ and $V_{D C}=112 \mathrm{~V}$ so that the load power is $610 \mathrm{~W}$ including the diode voltage drop. The simulation gives a result of $520 \mathrm{~W}$ of power delivered.

A simple chopper with current control can then be used to set the d.c. voltage. If it is too low then there is an over current, if it is too high then the generator is not being driven to its maximum generating capacity.

\section{Generator Design}

The paper has so far examined the operation of a permanent magnet motor when used as a generator under different conditions. We will now investigate the design of a radial-flux permanent magnet machine aimed at use in a small wind turbine application utilizing a Darrius design. The required operating specification is shown in Table III.

TABLE III

GENERATOR REQUIREMENTS FOR DARRIUS TURBINE

\begin{tabular}{|c|c|c|c|}
\hline Low speed & $87.5 \mathrm{rpm}$ & High speed & $350 \mathrm{rpm}$ \\
\hline Output power & $1 \mathrm{~kW}$ & Output power & $4 \mathrm{~kW}$ \\
\hline Proposed frequency & $23.3 \mathrm{~Hz}$ & Proposed frequency & $93.3 \mathrm{~Hz}$ \\
\hline Derived pole number & 32 & Derived pole number & 32 \\
\hline
\end{tabular}

\section{A. Initial Design-Internal Rotor}

The rated torque is $110 \mathrm{Nm}$. For a brushless permanent magnet machine, let us assume a torque per rotor volume of 30 $\mathrm{kNm} / \mathrm{m}^{3}$, which gives a sheer stress of $15 \mathrm{kNm} / \mathrm{m}^{3}$. This is a typical mid-range figure for this type of machine [14]. The rotor volume is therefore $3.7 \times 10^{-3} \mathrm{~m}^{3}$. To size the machine then assume an axial length to pole pitch of 1.5:1 (this is a better indication to the length of the machine rather than the axial length to rotor radius) which leads to a length to rotor radius ratio of 1:3.39. This gives an axial length of $46 \mathrm{~mm}$ and diameter of $316 \mathrm{~mm}$. The rotor volume is then $3.6 \times 10^{-3} \mathrm{~m}^{3}$. This prodcues the machine shown in Fig. 9 where the more detailed sizing and winding definition has taken place using the
SPEED PC-BDC design package. The winding layout is shown in Fig. 10. To size the machine the various Ranging exercises were conducted for a variety of parameters. This means that parameters were varied (or "Ranged") from one value to another and simulations conducted at set points.

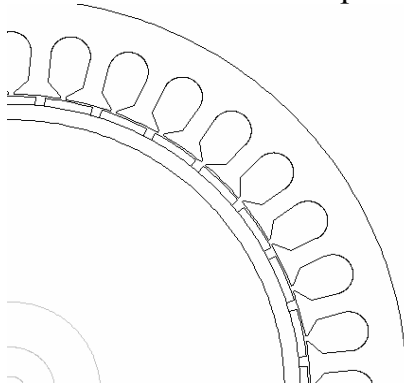

Fig. 9. Generator cross section for 32 pole internal rotor machine.

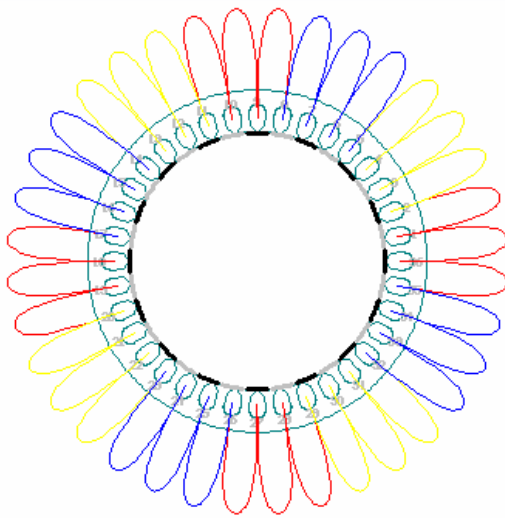

Fig. 10. Winding layout for 32 pole internal rotor machine.

Some key parameters that were ranged were the magnet length, tooth width, slot dept, winding thickness and several others. The main issues to address are the power factor and efficiency. The efficiency can be maximized simply by using reducing the copper loss. This involves sizing the slots and wire correctly. The performance figures at $87.5 \mathrm{rpm}$ and 350 $\mathrm{rpm}$ are given in Table IV. An example of the Ranging is shown in Fig. 11 where the magnet thickness is ranged and the output power (which is negative due to the default use of the motoring convention) and efficiency are inspected. It can be seen that a magnet thickness of about $4 \mathrm{~mm}$ offers about the best solution - beyond this the iterative increase in power is limited while the change in efficiency is negligible.

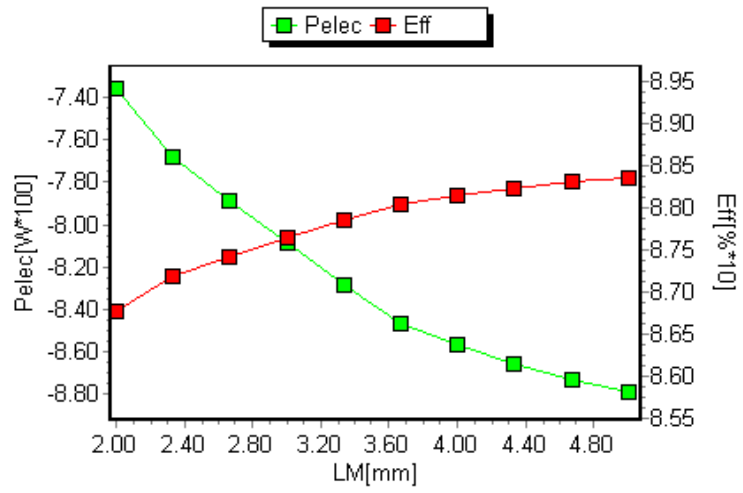

Fig. 11. Variation of machine output power and efficiency with magnet thickness using PC-BDC Ranging function. 
TABLE IV

GENERATOR PERFORMANCE FOR INTERNAL ROTOR MACHINE

\begin{tabular}{|c|c|c|c|c|c|c|c|}
\hline $\begin{array}{c}\text { Speed } \\
{[\mathrm{rpm}]}\end{array}$ & $\begin{array}{c}\text { Torque } \\
{[\mathrm{Nm}]}\end{array}$ & $\begin{array}{c}\text { Pout } \\
{[\mathrm{W}]}\end{array}$ & $\begin{array}{c}\text { Ephase } \\
{[\mathrm{V}]}\end{array}$ & $\begin{array}{c}\text { Vphase } \\
{[\mathrm{V}]}\end{array}$ & $\begin{array}{c}\text { Iphase } \\
{[\mathrm{A}]}\end{array}$ & $\begin{array}{c}\text { p.f. } \\
{[\mathrm{p} . \mathrm{u},]}\end{array}$ & $\begin{array}{c}\text { Eff } \\
{[\%]}\end{array}$ \\
\hline 87.5 & 106 & 857 & 45.7 & 46.0 & 7.1 & 0.89 & 88.1 \\
\hline 350 & 107 & 3734 & 182.9 & 197.1 & 7.1 & 0.90 & 95.2 \\
\hline
\end{tabular}

\section{B. External Rotor Re-Design}

This machine is suitable for inverting so that the rotor spins around the stator. This would be suitable for matching to the turbine. This has the effect of producing a more compact machine that uses less material. A direct inversion is shown in Fig. 12. This gives almost identical performance. To maintain the same tooth width then the slots do become narrower so that their depth has to be increased. The internal diameter is now $200 \mathrm{~mm}$ (internal rotor $=276 \mathrm{~mm}$ ) and external diameter 322 $\mathrm{mm}$ (internal rotor $=400 \mathrm{~mm}$ ). The axial length is kept at 46 $\mathrm{mm}$ and the airgap diameter at $300 \mathrm{~mm}$. The weight of the steel is reduced from $14.8 \mathrm{Kg}$ to $10.4 \mathrm{Kg}$ while there is a marginal increase in magnet weight and marginal decrease in copper weight. In addition, attaching surface magnets to a rotor can sometimes be difficult. The external rotor simplifies this since the centripetal force of the magnets is into the rotor core rather than away.

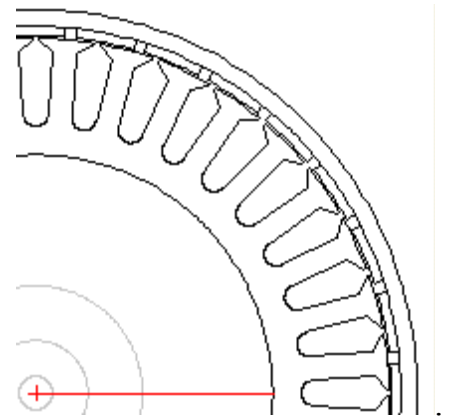

Fig. 12. Generator cross section for 32 pole external rotor machine.

\section{Diode Bridge Operation}

The machine specified in Section III. $A$ can be connected to a diode bridge rectifier. It was initially deigned as a low voltage machine so that at the low-end speed $(87.5 \mathrm{rpm})$ the back-EMF is $45.7 \mathrm{~V}$ at $23.3 \mathrm{~Hz}$. The winding inductance is $20.3 \mathrm{mH}$ while the phase resistance is $0.68 \mathrm{ohm}$. Taking the rated phase current as $7.07 \mathrm{~A}$ then an equivalent per-phase load resistance of $5.08 \mathrm{ohm}$ would deliver rated current and $756 \mathrm{~W}$ of power (compared to $857 \mathrm{~W}$ from PC-BDC simulation when the current is on the q axis). The PC-BDC simulation includes an iron loss of about $11 \mathrm{~W}$ which can be subtracted from the power delivered giving about $745 \mathrm{~W}$. This means there is a 13 $\%$ drop in power. However, using the Portunus model for the diode bridge then it is found from (5) and (6) that a load resistor of $9.05 \mathrm{ohm}$ is suitable but $7.6 \mathrm{ohm}$ gives a generator phase current of $7.07 \mathrm{~A}$. The power delivered to this load resistor is about $680 \mathrm{~W}$ showing a $21.7 \%$ decrease (if iron loss is added to the losses) compared to the PC-BDC simulation. The d.c. rail voltage is about $73 \mathrm{~V}$ at this load.

\section{Compact Machine Design}

The torque per rotor volume (TRV) was initially taken to be $30 \mathrm{kNm} / \mathrm{m}^{3}$, however [14] quotes a range up to 42 or even 50
$\mathrm{kNm} / \mathrm{m}^{3}$ for a totally enclosed motor and high performance servo. Therefore let us assume that the TRV can be increased to $45 \mathrm{kNm} / \mathrm{m}^{3}$ with the axial length maintained at $46 \mathrm{~mm}$. This would reduce the airgap diameter to $266 \mathrm{~mm}$. However, these guidelines are really aimed at low pole number motors, where the rotor is magnetic steel apart for a shaft and magnets. In high pole number machines the rotor is essentially hollow and these guidelines break down. The derived machine is shown in Fig. 13. The number of parallel turns has to be increased to account for the increased electric loading so that the slot area has to be increased. The output power at a current of $13.4 \mathrm{~A}$ is $733 \mathrm{~W}$ at $74.2 \%$ efficiency. The power factor is very low at 0.3 .

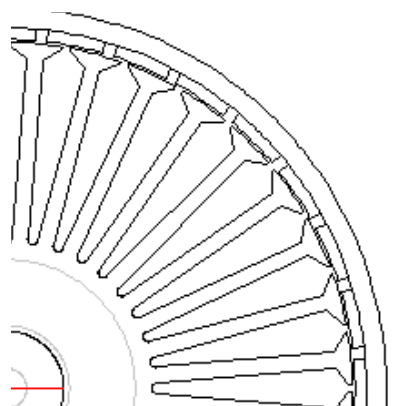

Fig. 13. Cross section for 32 pole external rotor machine and reduced diameter.

Because the airgap diameter is reduced then the torque for a given airgap sheer stress is less. Therefore the electric loading has to be increased (i.e., the current) to compensate. This has two effects. It increases the copper losses so that the efficiency decreases and it also increases the p.u. voltage drop across the phase reactance so that the power factor decreases. This will affect the operation in conjunction with a diode bridge rectifier. The phasor diagram with the current on the negative $\mathrm{q}$ axis (i.e., generating) is shown in Fig. 14. This illustrates that the voltage drop across the phase reactance is nearly 1 p.u. (compared to the phase voltage). The back-EMF at $87.5 \mathrm{rpm}$ is $24.7 \mathrm{~V}$ with a phase resistance of $0.45 \mathrm{ohm}$ and phase reactance of $4.46 \mathrm{ohm}$ If a resistive load is used (i.e., a diode bridge, then the maximum current at short circuit is $5.5 \mathrm{~A}$. This means that a controlled rectifier has to be used to utilize this machine as a generator.

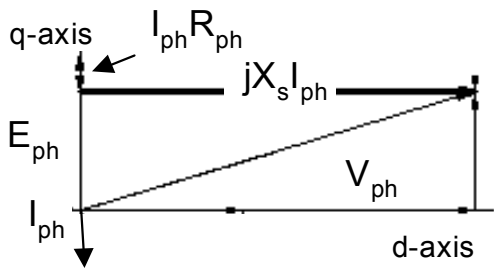

Fig. 14. Generating phasor diagram at full load and $87.5 \mathrm{rpm}$ for the compact machine. The current is $14.1 \mathrm{~A}$ on the negative $\mathrm{q}$ axis.

\section{E. Comparison of Machine Geometry and Performance}

The three different machines can be compared in terms of machine geometry and materials. The performances can then be compared in terms of low and high speed operation. The geometries are listed in Table V. The performances are given in Table VI. The coil layout is as shown in Fig. 10 and the coils are series connected. It can be seen that the external rotor machine is more compact than the internal rotor machine but 
gives almost identical performance. Both have low p.u. phase reactance so offer reasonable performance when used in conjunction with a diode bridge rectifier. However if the machine is further compacted then the electric loading has to be increased to the point where the power factor is poor and diode bridge rectification is not suitable.

TABLE V

32 Pole Generator Parameters For InTERnal Rotor, EXTERNAL Rotor AND COMPACT DESIGNS

\begin{tabular}{|c|c|c|c|}
\hline $\begin{array}{c}\text { Parameter (units in mm unless } \\
\text { otherwise stated) }\end{array}$ & $\begin{array}{c}\text { Internal } \\
\text { Rotor }\end{array}$ & $\begin{array}{c}\text { External } \\
\text { Rotor }\end{array}$ & $\begin{array}{l}\text { Compact } \\
\text { External }\end{array}$ \\
\hline Pole number & 32 & 32 & 32 \\
\hline Stator slot number & 36 & 36 & 36 \\
\hline Average airgap diameter & 301 & 301 & 145 \\
\hline Airgap length & 1 & 1 & 1 \\
\hline Outer diameter & 400 & 222 & 266 \\
\hline Inner diameter & 272 & 200 & 40 \\
\hline Axial length (stator and rotor) & 46 & 46 & 46 \\
\hline Magnet thickness & 4 & 4 & 4 \\
\hline Magnet width & 24.0 & 24.8 & 20.2 \\
\hline Magnet remanence $B_{r}[\mathrm{~T}]$ & 1.12 & 1.12 & 1.12 \\
\hline Magnet recoil premeability $\mu_{r e c}$ & 1.05 & 1.05 & 1.05 \\
\hline Number of coils per phase & 12 & 12 & 12 \\
\hline Coil pitch [slots] & 1 & 1 & 1 \\
\hline Turns per coil & 50 & 50 & 50 \\
\hline Wire strand diameter & 1.2 & 1.2 & 1.1 \\
\hline strands in hand & 2 & 2 & 3 \\
\hline Phase resistance $[\mathrm{ohm}]$ & 0.68 & 0.66 & 0.45 \\
\hline Phase inductance $[\mathrm{mH}]$ & 20.3 & 22.9 & 30.3 \\
\hline Slot depth & 32 & 37 & 70 \\
\hline Slot opening & 3 & 3 & 3 \\
\hline Slot area (unlined) & 502 & 415 & 620 \\
\hline Tooth width & 10 & 10 & 5.5 \\
\hline Slot fill (not including slot liner) & 0.45 & 0.54 & 0.46 \\
\hline Current density at rated $\mathrm{I}\left[\mathrm{A} / \mathrm{mm}^{2}\right]$ & 3.1 & 3.1 & 4.7 \\
\hline
\end{tabular}

TABLE IV

GENERATOR PERFORMANCE FOR INTERNAL ROTOR, EXTERNAL ROTOR AND COMPACT DESIGNS*

\begin{tabular}{|c|c|c|c|c|c|c|c|}
\hline $\begin{array}{c}\text { Generator } \\
\text { Design }\end{array}$ & $\begin{array}{l}\text { Speed } \\
{[\mathrm{rpm}]}\end{array}$ & $\begin{array}{c}\text { Torque } \\
{[\mathrm{Nm}]}\end{array}$ & $\begin{array}{l}\text { Pout } \\
{[\mathrm{W}]}\end{array}$ & $\begin{array}{c}\text { Ephase } \\
{[\mathrm{V}]}\end{array}$ & $\begin{array}{c}\text { Iphase } \\
\text { [A] }\end{array}$ & $\begin{array}{c}\text { p.f. } \\
\text { [p.u,] }\end{array}$ & $\begin{array}{l}\text { Eff } \\
{[\%]}\end{array}$ \\
\hline \multicolumn{8}{|c|}{ Low Speed (87.5 rpm) and current on q axis (controlled rectification) } \\
\hline Internal & 87.5 & 106 & 857 & 45.7 & 7.1 & 0.89 & 88.1 \\
\hline External & 87.5 & 101.8 & 823 & 43.9 & 7.1 & 0.86 & 88.2 \\
\hline Compact & 87.5 & 107.8 & 733 & 24.7 & 13.4 & 0.30 & 74.2 \\
\hline \multicolumn{8}{|c|}{ High Speed (350 rpm) and current on q axis (controlled rectification) } \\
\hline Internal & 350 & 107 & 3734 & 182.9 & 7.1 & 0.90 & 95.2 \\
\hline External & 350 & 102.6 & 3588 & 175.8 & 7.1 & 0.88 & 95.5 \\
\hline Compact & 350 & 108.5 & 3665 & 98.8 & 13.4 & 0.36 & 92.1 \\
\hline \multicolumn{8}{|c|}{$\begin{array}{l}\text { Low Speed }(87.5 \mathrm{rpm}) \text { and diode bridge rectification (*compact design does } \\
\text { not work with diode bridge) }\end{array}$} \\
\hline Internal & 87.5 & 91.1 & 680 & 45.7 & 7.1 & 1 & 81 \\
\hline External & 87.5 & 82.8 & 600 & 43.9 & 7.1 & 1 & 79.0 \\
\hline \multicolumn{8}{|c|}{$\begin{array}{l}\text { High Speed }(350 \mathrm{rpm}) \text { and diode bridge rectification }(* \text { compact design does } \\
\text { not work with diode bridge) }\end{array}$} \\
\hline Internal & 350 & 90.7 & 2950 & 182.8 & 7.1 & 1 & 88.8 \\
\hline External & 350 & 80.0 & 2650 & 175.6 & 7.1 & 1 & 90.4 \\
\hline
\end{tabular}

\section{CONCLUSIONS}

This paper illustrates simple steps that can be used to obtain a design for a suitable generator for a small wind turbine. It is split into two sections. The first section studies the performance of a brushless motor (designed for use in a water pump) when utilized in a generator application. This is a modern high-efficiency design with a low phase reactance and good power factor. The second section shows the design of a low-speed generator. Basic design principles are followed to realize the geometry and it is illustrated that an external rotor machine is more compact. An attempt was made to further compact the machine by reducing the diameter and increasing the electrical loading but it was found that this led to reduced efficiency and power factor. This was to the extent were a diode bridge rectifier load is inappropriate and a fully controlled rectifier would have to be used.

\section{REFERENCES}

[1] M. Chinchilla, S. Arnaltes and J. C. Burgos, "Control of PermanentMagnet Generators Applied to Variable-Speed Wind-Energy Systems Connected to the Grid," IEEE Trans on Energy Conversion, vol 21, pp 130-135, March 2006.

[2] Y. Higuchi, N. Yamamura, M. Ishida and T. Hori, "An Improvement of Performance for Small-Scaled Wind Power Generating System with Permanent Magnet Type Synchronous generator," IEEE Industrial electronics Annual Meeting IECON, pp. 1037-1043, 22-28 October 2000.

[3] O. Ojo, J. Cox and Z. Wu, "DC Power Generation Using Interior Permanent-Magnet Machine," IEEE Trans on Energy Conversion, vol 12, pp 351-256, December 1997.

[4] N. Naoe, "Voltage Compensation of Permanent-Magnet Generator with capacitors," IEEE International Electric Machines and Drives Conference, pp. WB2 14.1-14.3, 18-21 May 1997.

[5] O. Ojo and J. Cox, "Investigation into the Performance Characterisitics of an Interior Permanent Magnet Generator Including Saturation Effects," IEEE Industry Applications Society Annual Meeting,, pp 533540, 6-10 October 1996.

[6] A. Binder and T. Schneider, "Permanent magnet synchronous generators for regenerative energy conversion - a survey," European Conference on Power Electronics and Applications, 11-14 September 2005.

[7] E. Spooner and B. J. Chalmers, "Torus': A slotless toroidal-stator, permanent-magnet generator," IEEE Proceedings-B, vol. 139, pp. 497506, November 1992.

[8] M. A. Rahman, A. M. Osheiba, T. S. Radwan and E. S. Abdin "Modelling and Controller Design of an Isolated Diesel Engine Permanent Magnet Synchronous Generator," IEEE Trans on Energy Conversion, vol. 11, pp 324-330, June 1996.

[9] J. Rizk and M. Nagrial "Design of Permanent-Magnet Generators for Wind Turbines," Third International Conference on Power Electronics and Motion Control, pp 208-212, Beijing, 15 -18 August 2000.

[10] K.-C. Kim and J. Lee "The Dynamic Analysis of a Spoke-Type Permanent Magnet Generator with Large Overhang," IEEE Trans on Magnetics, vol. 41, no. 10, pp 3805-3807, October 2005.

[11] W. Wu, V. S. Ramsden, T. Crawford and G. Hill "A Low Speed HighTorque Direct Drive Permanent Magnet Generator for Wind Turbines," IEEE Industry Applications Society Annual Meeting,, pp 147-154, Rome, 8-12 October 2000.

[12] Z. Chen, E. Spooner, W. T. Norris and A. C. Williamson, "CapacitorAssisted Excitation of Permanent-Magnet Generators," IEE Proc. Electrical Power Applications, vol. 145, pp 497-508, November 1998.

[13] H. Polinder, F. F. A. van ser Pijl, G.-J. de Vilder and P. Tavner, "Comparison of Direct-Drive and Geared Generator Concepts for Wind Turbines," IEEE International Conference on Electrical machines and Drives, pp 543-550, 15-18 May 2005.

[14] J. R. Hendershot and TJE Miller, "Design of Brushless permanent Magnet Motors", Magna Physics Publishing and Clarendon Press Oxford, 1994. 